\title{
RESENHA: Grupos e exclusão escolar: os nós que amarram a inclusão e os laços que a envolvem
}

\author{
Lazslo Antonio Ávila \\ Faculdade de Medicina de São José do Rio Preto-SP, São José do Rio Preto-SP, Brasil
}

Emílio, S. A. (2008). Grupos e inclusão escolar: Sobre laços, amarras e nós. São Paulo: Paulus.

Grupos e inclusão escolar: Sobre laços, amarras e nós, de Solange Aparecida Emílio, é um livro necessário. Muitos livros são escritos, mas nem todos são necessários. Por que este é necessário? Este pequeno livro foi uma grande tese acadêmica, defendida com brilhantismo no Instituto de Psicologia de Universidade de São Paulo no final de 2004, e levantou tantas questões que a banca, da qual participei, foi unânime em recomendar sua publicação. É preciso colocar para o debate público o que pensam e o que enfrentam os profissionais da Educação que se devotam à árdua tarefa de incluir - e refletir sobre o que isto significa.

É necessário discutir ampla, profunda e continuamente o papel da Educação em um mundo tão cambiante como este que nos toca viver. Tudo muda rapidamente: novas teorias e novas técnicas seguem o ritmo frenético das mudanças históricas, mudam valores, modelos, paradigmas, comportamentos e instituições. As fronteiras físicas e mentais são continuamente alargadas ou invadidas. Novos modos de subjetivação emergem, ao mesmo tempo em que o ambiente físico e cultural transmuta. Para não nos perdermos necessitamos de critérios, balizas para orientar ações e decisões, pontos de ancoragem para discriminar as mudanças necessárias das fúteis. Necessitamos referências. Principalmente na área da formação dos novos cidadãos.

A inclusão não pode ser apenas um modismo intelectual. Não pode ser banalizada e descartada tão logo apareça um novo rótulo, ou novos gurus. Mesmo que seu nome vá para o museu das idéias, a sua concepção deve ser revitalizada. É isto o que Solange faz neste livro muito bem escrito, reflexivo e abrangente. Trata de questões de forte significado social: como proceder às mudanças estruturais necessárias para que a inclusão não seja apenas um desejo, mas uma prática efetiva de transformações.
A autora "toca o dedo em muitas feridas", mas o faz com cuidado clínico: para não ferir, não contaminar, não infectar. É preciso pensar e agir cautelosa, mas firmemente. A inclusão não pode ser uma atitude provisória e hesitante; incluir o diferente envolve muito mais coisas do que simples decretos ou teses acadêmicas muito críticas e pouco sábias. Incluir é uma luta tão árdua quanto transformar estruturas de poder e privilégio. Neste livro encontra-se um claro compromisso: pensar eticamente. A autora apresenta a ética como a busca da perfeição das pessoas, e descreve o bem como "aquilo que aprimora a natureza".

Sabe-se o quanto é difícil mudar mentalidades. Exige tempo, esforço, saberes e métodos. A teoria dos grupos nascida da psicanálise das configurações vinculares e o próprio conceito de vínculo sem dúvida são ferramentas imprescindíveis. Uma práxis comprometida com a Educação e com o desenvolvimento social, um ativo olhar-pensar, uma cuidadosa análise institucional e uma permanente vigilância crítica sobre os processos e os resultados, tudo isso é necessário. Depois é preciso sistematizar uma investigação.

E aqui vemos uma interessante simbiose: o investigador é o foco e o alvo de seu próprio estudo, pois ele (ela) foi o sujeito destas ações que vão ser discutidas. Houve critério e ajustes, pois Solange, a partir de seu trabalho concreto em uma instituição escolar, vai se dedicar a produzir pensamento sobre o trabalho realizado. Neste livro, sua prática tomou o interessante formato de vinhetas: misto de fato e criação, as situações que ela elegeu para nos apresentar se constituem em verdadeiros protótipos das situações-problema da inclusão. Pode-se dizer que são como arquétipos das questões fundamentais de uma educação democrática.

A pesquisa acadêmica de Solange gerou fatos de modo a torná-los pensáveis. Apesar de condensa- 
ções de situações escolares reais, o que vemos são elementos essenciais para o delineamento dos procedimentos necessários para o seu enfrentamento. Buscando contornar o espinhoso tema da apresentação de pessoas reais, em situações inclusivas críticas, Solange imaginou e descreveu com clareza:

(1) A problemática situação da inclusão da deficiência mental - Marcos ${ }^{1}$ é uma criança diagnosticada como deficiente. O convívio com ele trazia para sua classe e seus professores inúmeras dificuldades, devido a seu comportamento agressivo e seu interesse sexual excessivo. O manejo da situação conduz a uma ampliação do que significa "aceitar”, e o aproxima das reflexões antropológicas da aceitação de pessoas etnologicamente distintas de nós.

(2) A interferência da estrutura familiar sobre a escola - o caso de Lucas expõe todas as limitações inerentes ao processo inclusivo quando os segredos familiares (no caso, a idade real da criança) se impõem, gerando resistências a qualquer mudança. Demonstra os limites técnicos frente à impossibilidade de analisar e transformar terapeuticamente as estruturas familiares, às vezes transgeracionais, que transformaram um filho no sintoma de uma família.

(3) As questões sociais e institucionais impondo o fracasso da inclusão - Malu é uma menina adotada, vivendo um trágico momento de desestruturação familiar. Os agentes institucionais e o Conselho Tutelar fracassam em sua função, e sobra para a escola uma tarefa para a qual não dispõe de todos os recursos necessários; e dada sua função social, de prover educação aos alunos e não cuidar de todo o grupo familiar.

(4) As dificuldades singulares com o processo simbólico - a estória de Bárbara permite acompanhar a necessidade da ampliação de métodos e de diversificação de abordagens que propiciem o respeito às singularidades de cada sujeito. Não apenas adaptar o indivíduo ao mundo, mas adaptar a escola a cada um de seus membros.

(5) A extrema dificuldade de incluir os autistas - Flávio é um autista, por definição um sujeito que recusa a comunicação e o convívio. A escola, espaço

\footnotetext{
${ }^{1}$ Os nomes aqui relatados são fictícios a fim de preservar a identidade dos participantes da pesquisa.
}

privilegiado da socialização, enfrenta esse desafio "abrindo suas janelas": cognitivas, emocionais, interativas, vinculares. $\mathrm{O}$ autismo é a máxima diferença. Incluir o autista é experimentar os limites do processo inclusivo: aceitar o outro em sua radical dessemelhança.

(6) E quando é o professor que precisa ser incluído? Juliana é uma professora cega. Seu caso apresenta toda a complexidade e a lucidez que se necessita para manejar o conjunto de fatos novos que são gerados a partir da decisão de incluir. Este interessante relato demonstra a obrigatoriedade de discutir a inclusão com os próprios interessados. É preciso vontade política, esforço intelectual, técnico e material e um contínuo processo de discussão transformadora.

(7) E ainda casos de conflitos familiares, de hiperatividade, psicoses e outros, conformam um riquíssimo material de reflexão, demonstrando as possibilidades de uma atuação favorecedora de mudanças nas práticas educacionais e todo o conjunto de resistências que emerge frente às transformações, mesmo as inevitáveis. De todos os relatos ressaltase a dimensão ética e crítica que vê na escola não apenas um espaço de transmissão cultural, mas um local de produção de novos vínculos e de novas formas de socialização e produção cultural.

Este trabalho corajoso e lúcido tem uma vocação: tornar-se material pedagógico, instrumento para a preparação de professores, coordenadores pedagógicos, diretores, psicólogos educacionais, pais e filhos, para formas cada vez mais consequientes da tarefa de educar a todos, visando, como diz a autora, um mundo melhor.

Resenha recebida em 21/02/2008.

Aceita para publicação em 15/05/2008.

Endereço para correspondência:

Prof. Dr. Lazslo Antonio Ávila. Departamento de Psiquiatria e Psicologia Médica. Faculdade de Medicina de São José do Rio Preto. Av. Brig. Faria Lima, 5525. CEP: 15000-000. São José do Rio PretoSP, Brasil.E-mail: lazslo@terra.com.br

Lazslo Antonio Ávila é Professor Adjunto da Faculdade de Medicina de São José do Rio Preto. 